\title{
HUMANITÁRIUS KATASZTRÓFA ÉS ÖKOLÓGIAI VESZÉLYEK - TÉNYEK A HÍRHEDT NÖVÉNYKÓROKOZÓ PHYTOPHTHORA-NEMZETSÉGRŐL
}

\section{HUMANITARIAN CATASTROPHE AND ECOLOGICAL THREATS - FACTS ABOUT THE INFAMOUS PLANT PATHOGENIC GENUS PHYTOPHTHORA}

\author{
Érsek Tibor \\ DSc, professor emeritus, Széchenyi István Egyetem Mezőgazdaság- és Élelmiszertudományi Kar, Mosonmagyaróvár \\ ersek.tibor@sze.hu
}

\begin{abstract}
ÖSSZEFOGLALÁS
E dolgozat a természettudományok egy szűk, de annál fontosabb területére, a növénykórtanra kívánja felhívni a figyelmet oly módon, hogy a növénykórokozó mikroszervezetek egy különleges csoportjára, a Phytophthora-nemzetségre összpontosít. E nemzetség elsőként azonosított képviselője a hírhedt Phytophthora infestans, amely a burgonyavész kórokozójaként szörnyű éhínséget váltott ki Îrországban a 19. század közepén. Azóta 184 fajjal bővült a nemzetség! Ez a váratlan fajszámrobbanás egyéb tényezők mellett elsősorban a molekuláris azonosítási módszerek elterjedésének tulajdonítható. A nemzetség olyan fajokat, sőt fajhibrideket foglal magában, amelyek többsége igen veszélyes kórokozóként a Ph. infestansszal vetekszik az ökológiai és a gazdasági jelentősége révén. Következésképpen a mai tényállás és a feltételezés, hogy még több száz faj rejtőzködik a természetben, sajátos kihívás elé állítja a növénykórtani és növényvédelmi szakembereket.
\end{abstract}

\section{ABSTRACT}

The purpose of this report is to introduce readers to a small but important segment of natural sciences, i. e. plant pathology, focusing on the infamous genus Phytophthora of plant pathogenic microorganisms. Ever since the finding and description of Phytophthora infestans responsible for the mid-19 ${ }^{\text {th }}$ century Irish famine, a great number of additional species (184 to date) has been discovered. This unexpectedly rapid upswing of species is certainly associated with the advent of molecular techniques and several other factors. The genus Phytophthora includes species, moreover, interspecific hybrids that are harmful plant pathogens whose ecological and economic importance is in congruence with that of the 'plant killer' Ph. infestans. Therefore, the recent situation and the assumption that there might be several hundreds of as yet unknown species in nature, pose unique challenges to plant pathologists and plant protection experts.

Kulcsszavak: Phytophthora infestans, Phytophthora-nemzetség, fajszámrobbanás, fajhibridek, evolúciós változások, ökológiai összefüggések, növényvédelmi kihívások

Keywords: Phytophthora infestans, the genus Phytophthora, species upswing, interspecific hybrids, evolutionary changes, ecological aspects, challenges in plant protection 


\section{BEVEZETÉS}

Kevés olyan növénykórokozó mikroorganizmus van, vagy tán nincs is, amelyet akkora érdeklődés kísérne, mint a Phytophthora-nemzetség fajait (a fitoftórákat). A Phytophthora-történet a valószínúleg Amerikából behurcolt Phytophthora infestansszal és az általa előidézett, tragikus kimenetelü burgonyavésszel kezdődött. Írországban, 1845-ben és az azt követő három-négy évben a vész hatalmas méretü járvánnyá fajult, amely teljesen kipusztította az írek elsődleges tápláléknövényéül szolgáló burgonyát. Nem véletlen tehát, hogy a kórokozó végleges nemzetségneve a görög phyto (= növény) és phthora (= pusztító) szavakból állt össze: Phytophtho$r a$, azaz növénypusztító. De akár emberpusztítónak is elnevezhették volna, hiszen ez az ámokfutó mikroszervezet valójában humanitárius katasztrófát idézett elő. Ugyanis több mint egymillióan haltak éhen, és legalább ennyien kényszerültek elhagyni Írországot a burgonyavészjárvány nyomán fellépő éhínség miatt. Azóta 184 fajjal bővült a nemzetség! Jó néhányuk olyan ökológiai veszélyeket rejt magában, amelyek alapján akár versenyre is kelhetnek a burgonyavész kórokozójával.

\section{MIK IS EZEK A FITOFTÓRÁK?}

A Ph. infestans volt az első mikroszervezet, melyet gombaként azonosítottak. Ezt követően újabb és újabb fajokat fedeztek fel a nemzetségben. Később derült ki róluk, hogy voltaképpen identitászavarban szenvednek. A növénykórokozóknak egy olyan sajátos csoportját alkotják ugyanis, amelynek tagjai bár habitusban (a fonalas szerkezet révén) a gombákat idézik, a filogenetikai vizsgálatok alapján nem tekinthetők gombáknak. A régebben moszatgombákként jegyzett fitoftórákat és rokonaikat (például a peronoszpórákat) tehát ma már nem gombákként, hanem gombaszerü szervezetekként tartják számon, és a moszatokkal rokonítva rendszerezik öket. Az igazi gombáktól különböznek - egyben a moszatokhoz hasonlítanak - többek között a riboszomális RNS-ek bizonyos génjeiben, valamint abban, hogy a sejtfaluk glükánokból (glükózmolekulák elágazó polimerjeiből) és nem kitinből (acetil-glükozamin polimerekből) épül fel, illetve életciklusukban a diploid és nem a haploid szakasz dominál. Vannak közöttük bizonyítottan veszedelmes és látszólag kevésbé káros kórokozók egyaránt.

Ivartalan szaporítóképleteik a sporangiumok és e tokszerü képletekben kialakuló zoospórák. Csapadékos időben egy-egy sporangiumból több tucat zoospóra rajozhat ki kétostoros mozgással. Maguk e spórák egysejtüek és sejtfal nélküliek, amelyek különböző vegyi és/vagy mechanikai (például a növényfelülettel való érintkezés) hatásra pillanatokon belül képesek ostoraikat levetve sejtfalas, statikus képletekké alakulni, majd behatolni a növényi szövetbe. Egyes fajok sporangiumai - különösen vízhiányos időben - nem zoospórákkal, hanem közvetlenül 
csíráznak, vagyis egy sporangium egyetlen ponton fertőz. Nyilvánvaló, hogy a betegség terjedése és így a járványveszély is akkor nagyobb, amikor a fertőzés a zoospórák tömegéből indul ki.

A nagy populációs diverzitást biztosító ivaros szaporodásuk folyományaként ún. oospóra (zigóta) fejlődik, amely vastag falának tulajdoníthatóan éveken át képes kiirthatatlanul fennmaradni a talajban és újabb nemzedékeket létrehozni. A fitoftórák egylakiak: hím és női ivarszerveik egyazon telepen képződnek. Vannak fajok, amelyeknél az egyesülés ugyanott be is következik (homotallizmus). Más fajoknál (ilyen a Ph. infestans is) viszont kétféle párosodási (A1 és A2) típusú egyedek ivarsejtjeinek kölcsönhatása szükséges az ivaros folyamat megvalósulásához (heterotallizmus). Ha a heterotalliás fajok adott populációjában nincsenek jelen a mindkét párosodási típust képviselö egyedek (vagyis az ivaros folyamatainak tér- és/vagy időbeli akadályai vannak), akkor az adott faj egyedfejlödése kizárólag az ivartalan ciklusra épül, mint ahogy ama (sterilisnek tartott) fajoké is, amelyek képtelenek ivaros szaporodásra. Ilyenkor a faj klónos szaporodású, vagyis populációja lényegében homogén.

Különlegességük, mondhatni furcsaságuk, no meg a sokféle növényen való súlyos károkozásuk, nem utolsósorban pedig a minden más mikroszervezeténél nagyobb és folyamatosan növekvő fajszámuk állítja e szervezeteket a kórtani és növényvédelmi kutatások egyik középpontjába, napjainkban különösen.

A fitoftórákról megjelent összefoglaló munkák sokaságában kiemelkedő jelentőségü a Donald C. Erwin és Olaf K. Ribeiro (1996) által írt kézikönyv, amely szinte mindent magában foglal, amit a fitoftórákról addig tudni lehetett, többek között 58 Phytophthora-faj részletes, fenotípusos (morfológiai, élettani, patogenitási) tulajdonságokon nyugvó ismertetését is.

Érdekesség, hogy az első négy fajt (kezdve a hírhedt Ph. infestansszal) még a 19. század utolsó évtizedeiben azonosították, aztán a következő száz évben mintegy 40-et, 1980 és 1996 között pedig tizennégyet írtak le. Ezt követően jött a nagy fordulat, egy valóságos fajszámrobbanás (1. ábra). A mai napig 126-tal gyarapodott a szakszerủen azonosított fajok száma, vagyis jelenleg 184 fajról van tudomásunk (Érsek, 2017) ${ }^{1}$.

Egy nemrégiben végzett nemzetközi felmérés szerint (Kamoun et al., 2015) gazdasági és/vagy tudományos szempontból legfontosabb fitoftórafajok, sorrendben: a burgonyát és a burgonya rokon növényeit támadó $P h$. infestans, a hirtelen tölgyhalálért és egyéb növények pusztulásáért felelős $P h$. ramorum, a szóját támadó $P h$. sojae, a paprikát és elsősorban rokon növényeit támadó $P h$. capsici, valamint az igen sok növényfajt megbetegítő (polifág) $P h$. cinnamomi és a $P h$. nicotianae (2. ábra).

\footnotetext{
${ }^{1}$ A jelzett irodalomban még 173 faj szerepel, 11-et azóta írtak le.
} 


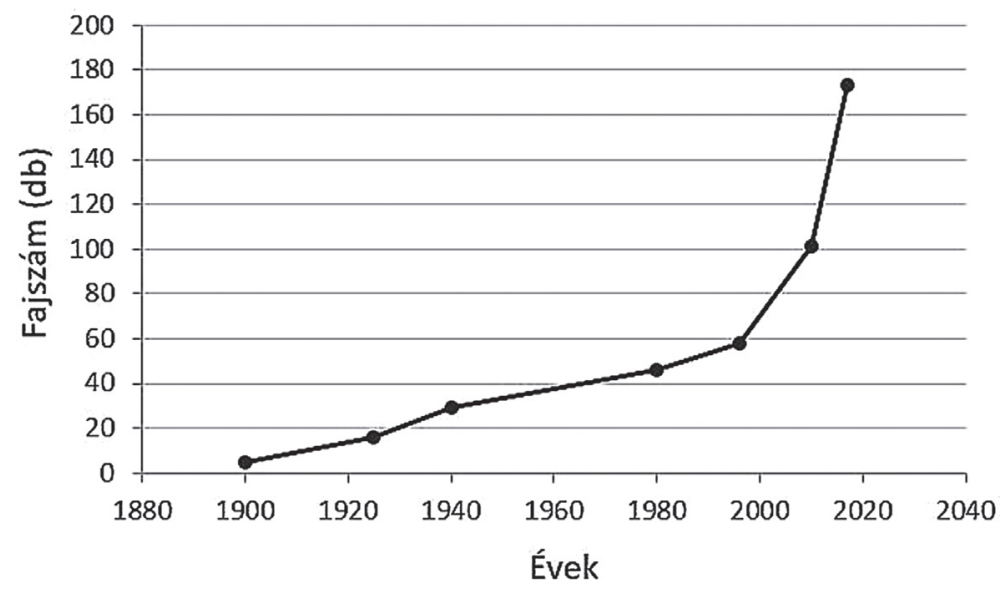

1. ábra. Az azonosított Phytophthora-fajok száma a jelzett időpontokban (saját szerkesztés)

Ökológiai szempontból legveszélyesebbnek a Ph. cinnamomit és a $P$ h. ramorumot tartják. A Ph. cinnamomi „,biológiai buldózerként” pusztít Ausztrália és Dél-Afrika természetes és mesterséges ökoszisztémáiban, a nemrégiben felfedezett $P h$. ramorum pedig Észak-Amerikában és Európában főleg az erdei ökoszisztémák növényfajait tizedeli. A fenti sorrendből kitünik továbbá, hogy a csaknem másfél évszázados múltra visszatekintő $P h$. infestans manapság sem minősül lerágott csontnak, hiszen a burgonyán kívül annak rokon növényeit (paradicsomot, padlizsánt stb.) szintén betegíti.

A régebbi, vagyis az 1996-ig ismert fitoftórák faji leírásai kizárólag fenotípusos bélyegeken alapulnak. Tudvalévő azonban, hogy e szervezetek ilyen alapon való azonosítása meglehetősen komplikált feladat. Részben a fajon belül mutatkozó eltérések, esetenként pedig a fajok közötti - gyakran környezetfüggő - átfedések jelentenek buktatót. Fokozza az azonosítási nehézségeket az is, hogy számos faj in vitro csak bizonyos stimulusok hatására (vagy még úgy sem) fejleszti ki azokat az ivartalan és/vagy ivaros képleteket, amelyek nélkülözhetetlenek a morfológiai alapú azonosításhoz. Márpedig a kórokozó pontos ismeretének hiánya nehezíti az ellene való védekezés kidolgozását, ami egyébként még ismert faj esetében is nehézségekbe ütközhet, kiváltképp amikor populációjában felülkerekednek az aktuális növényvédő szerrel szemben rezisztens egyedek.

Ugrásszerủ fejlődést hozott a fitoftórák kutatásában az, hogy a fenotípusos tulajdonságokon nyugvó és esetenként kételyeket támasztó azonosítási módszer mellé felzárkózott a molekuláris diagnosztika. A molekuláris szintủ azonosítások elsősorban a sejtmag riboszomális (r) DNS-e ITS szakaszainak, illetve más nukleáris, valamint mitokondriális gének vagy génszakaszok szekvenciaelemzésére épülnek. Ezzel nem csupán az azonosítás lett megbízhatóbb, hanem lehetővé vált 
a fajok filogenetikai összefüggéseinek feltárása, valamint a populációk genetikai szerkezetének, így a mutációkból és/vagy intra- és interspecifikus kölcsönhatásokból eredő változatosságának megismerése.

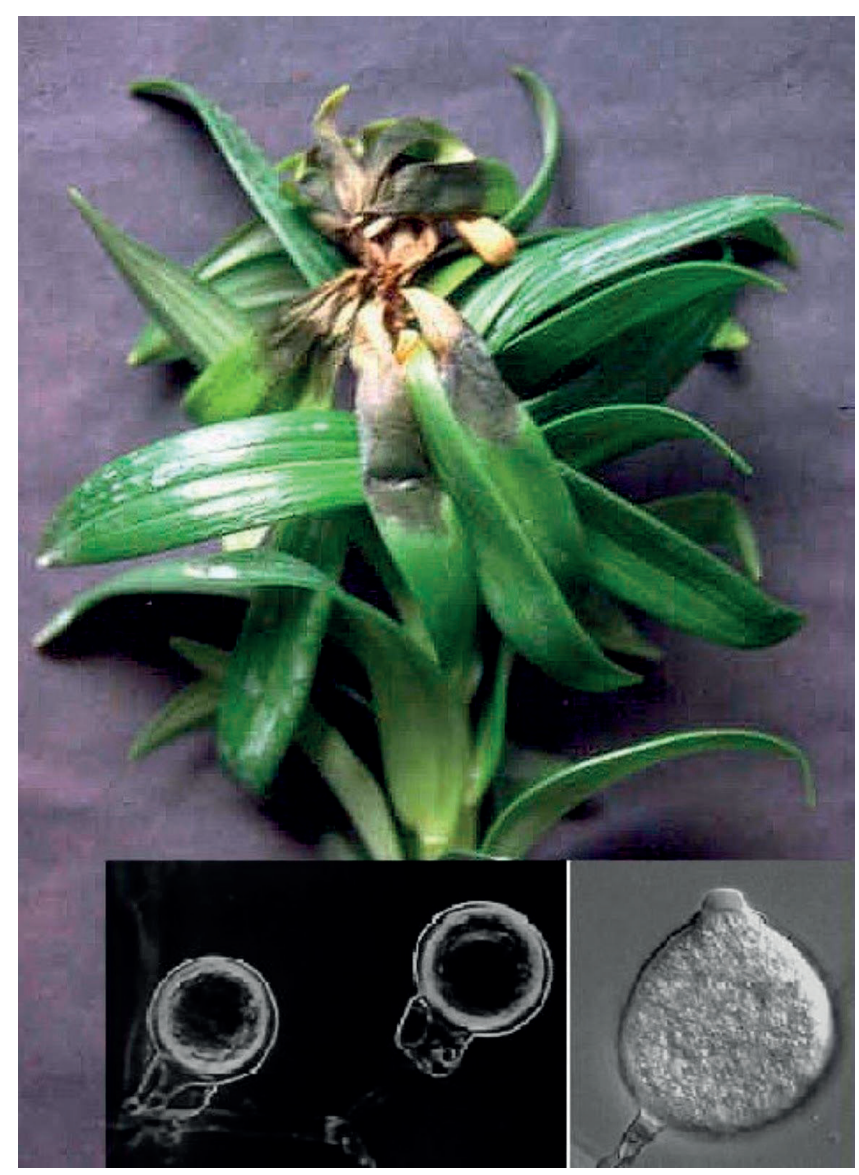

2. ábra. A sokgazdás Phytophthora nicotianae tetemes károkat okozott liliomon egy hazai kertészetben. A betegség tünetei, illetve a kórokozó ivaros spórái és sporangiuma (a szerző fotója)

Az említett fajszámrobbanás és a vele összefüggő evolúciós folyamatok egyelöre beláthatatlan környezeti veszélyeket rejtenek magukban, és a fitoftórákat továbbra is a tudományos érdeklődés fókuszában tartják. Talán ez a kitüntetett figyelem késztetett egy külföldi szakmabelit, hogy blogjának a következő címet adja If I were a plant pathogen, I would want to be a Phytophthora species (Ha növénypatogén volnék, akkor egy fitoftórafaj akarnék lenni, Joey Hulbert: sayasblog.com, 2016. 03. 17.). 


\section{ÖKOLÓGIAI ALARM}

\section{Parazitizmus}

A fitoftórák a legkülönbözőbb (természetes és mesterséges [mezőgazdasági]) ökoszisztémákban fordulnak elö. Egyes fajok jelenleg csak egy-egy régióban ismertek (például a Ph. nagaii Japánban), mások viszont (például Ph.. nicotianae, $P h$. niederhauserii) valamennyi lakott kontinensen jelen vannak. Érdekes, hogy a legtöbb fajt eddig Európából és az amerikai földrészről jelezték. Amióta - mintegy másfél évtizede - Ausztrália is bekapcsolódott az intenzív kutatásba (külön fitoftórakutató intézet létesült), számos faj kizárólag ott vált ismertté. Ázsiában korábban Japánból, Nepálból és Tajvanról, Afrikát illetően pedig csupán Dél-Afrikából és Elefántcsontpartról jeleztek új fajokat, jóllehet ez a két kontinens potenciális ,,aranybánya” lehet.

Mai ismereteinken továbblépve elképzelhető az előzőekben vázoltnál bonyolultabb és veszélyesebb fejlemény is, amit néhány példa már eddig is igazol. Egy adott régióban és/vagy ökoszisztémában talált faj ugyanis átterjedhet egyéb élöhelyekre, esetleg spontán kialakulhat más régiókban, illetve ökoszisztémákban. Egy széles körü, huszonhárom európai ország több száz kertészetében, faiskolájában, tájkertészeti és egyéb telepített növényállományaiban végzett felmérés szerint a hatvannyolc izolált fitoftórából negyvenhét behurcoltnak tekinthető.

Parazitizmusukat illetően a fajok között vannak széles gazdakörüek (polifágok), mint például a $P h$. niederhauserii, szük gazdakörűek, mint a salátát megbetegítö $P$ h. lactucae, illetve olyanok (például a Ph. stricta), amelyek szaprotrófnak tünnek. További veszélyforrás lehet, amikor valamely gazdanövényéröl egyéb, föleg rokon növényekre kerülve a szük gazdaspektrumú fajok kiszélesítik eredeti gazdakörüket, azaz patogenitásukat. Hasonlóképpen a szaprotróf(nak tünő) fajok (például Ph. aquimorbida) megfelelö környezetbe (például víztározóból növényre) kerülve parazitává válhatnak, amire már példa is akad. Ráadásul kiemelt, de talán mégsem oly váratlan veszélyt jelentenek a sokgazdás és nagy ökológiai plaszticitású fajok, így például azok, amelyek tág hőmérsékleti határok között képesek növekedni (például Ph. borealis, Ph. lacustris stb.). Ez utóbbi tulajdonságuk révén jól alkalmazkodnak a globális éghajlati változásokhoz, elvileg a hömérsékleti tényezők kevéssé korlátozzák terjedésüket akár észak-déli, akár délészaki irányban.

\section{Fajhibridek}

A fitoftórák evolúciójában fontos szerepet játszik egy adott faj populációjának egyedei között létrejövő (intraspecifikus) géncsere. Ám ma már azt is tudjuk, hogy közeli rokon fajok genetikai kölcsönhatása (interspecifikus hibridizáció) 
szintén bekövetkezhet, melynek eredményeként fajhibridek keletkeznek. A jelenséget - ami a növény- és állatvilágban régóta ismeretes - a gombák, illetve gombaszerủ szervezetek körében sokáig csak feltételezték. Abból kiindulva, hogy valamely növényt egyszerre két vagy több rokon szervezet is megtámadhat, elképzelhető a fertőző fajok közötti genetikai kölcsönhatás. A szerző és munkatársai bizonyították először molekuláris szinten is, hogy - legalábbis laboratóriumi körülmények között - valóban lehetséges két rokon Phytophthora-faj hibridizációja, mégpedig az ivartalan szaporítóképletként funkcionáló zoospórák indukált egyesítése révén (Érsek et al., 1995).

Nagyjából ezzel egy időben Nagy-Britannia déli részének természetes erdei ökoszisztémáiban 15-20\%-os égerpusztulásra figyeltek föl a szakemberek. Ennek kapcsán a New Scientist 1999. májusi számában meghökkentő címủ szerkesztöségi cikk jelent meg, amely az európai égereseket veszélyeztető „ördögi gomba ámokfutására" hívta fel a figyelmet. Ez az égervészt kiváltó kórokozó volt a természetben elsőként felfedezett fitoftórahibrid, amelyet látszólag stabilizálódott genomja okán fajként (Ph. alni) határoztak meg (Brasier et al., 2004).

A hibridek kialakulásában az ivaros rekombináció tünik meghatározónak. Ezt támasztja alá az a tény is, miszerint egyes heterotalliás (nem feltétlenül közeli rokon) fajok, amelyeknek eddig csak az az egyik (A1-es) párosodási típusa ismert, könnyen párosíthatók közös tenyészetben más heterotalliás fajok A2-es párosodási típusával. Ezzel szemben az égervész kórokozójának esetében a paraszexuális út látszik megvalósulni, amikor is szomatikus sejtek (hifák vagy zoospórák) egyesülésével aneuoploid (a nemzetségre jellemző kromoszóma-alapszerelvénytől több kromoszómával eltérö) utód jön létre.

Mint súlyos gazdasági problémákat magában rejtő s ezzel új kihívásokat jelentő interspecifikus hibridekröl hajlamosak vagyunk azt hinni, hogy a jelen kor szülöttei, hiszen lényegében csupán az utóbbi tízegynéhány évben hallunk róluk. Herbáriumi anyagok molekuláris biológiai vizsgálatából azonban kitünik, hogy például a nyárfa rozsdagombájának fajhibridjei már legalább egy évszázaddal ezelőtt előfordultak az USA-ban (csak éppen morfológiai alapon nem lehetett a hibridjelleget kimutatni) olyan területeken is, amelyek kívül estek a szülőfajok tipikus élőhelyein.

Mivel manapság a korábbiakhoz mérten szokatlan feltételek gyakrabban föllépnek - föleg a természet rendjébe beavatkozó emberi tevékenység révén -, nagyobb valószínüséggel kerülhetnek növények és kórokozóik olyan körülmények közé, amelyek lényegesen fölgyorsíthatják az ilyen jellegủ evolúciós jelenségeket.

Minél nagyobb a rokonsági fok, annál nagyobb az esély két faj hibridizációjára. Az eddig feltárt tucatnyi természetes Phytophthora-fajhibrid mindegyike közeli rokon szülőktől származik. Jelenleg úgy tünik: a hibridizációs folyamatok esélyét növeli, amikor egymástól korábban elszigetelten élő fajok kerülnek hirtelen közös 
és számukra természetellenes területre/növényre anélkül, hogy kifejleszthették volna a genetikai kölcsönhatásokat kizáró mechanikai-biokémiai gátakat. Vagyis legvalószínübb a hibridizáció egy adott régióban honos faj és egy behurcolt faj vagy két behurcolt faj között. Az elöbbire példa az a hibrid (Ph. ×pelgrandis), amelyet hollandiai hidroponikus kultúrában nevelt dísznövényekről izoláltak, később pedig Peruban és Tajvanon, természetes ökoszisztémában találtak meg. Szülöfajai közül Európában a Ph. cactorum a honos, a Ph. nicotianae pedig a behurcolt, a két távoli országban viszont pont fordított a helyzet. Mindez arra utal, hogy a hibridizációs események nagyjából egyidejüleg több helyen is végbemehetnek, és a hibrid kórokozó további evolúciója egyes régiókban/ökoszisztémákban eltéröen zajlik.

Az előző példával szemben az Európa-szerte elterjedt égerfitftóra feltételezett szülöfajai (Ph. cambivora és egy Ph. fragariae-szerü faj) egyaránt behurcolással kerülhettek a kontinensre. A hibridizáció valószínúleg a szülök közös gazdanövényén, a málnán következett be, s az így keletkezett hibrid egy olyan növényre (az égerre) terjesztette ki patogenitását, amelyik egyik szülőnek sem a gazdája.

A legújabb ausztráliai kutatások arra utalnak, hogy a honos fajok között szintén végbemegy hibridizáció. Folyóvízi és vizes erdei ökoszisztémában honos közeli rokon fajok különbözö kombinációban hibridizáltak. Szakszerü leírásuk azonban elmaradt, mivel e hibridek állandó átalakulásban vannak, tenyészetben pedig alig vagy egyáltalán nem tarthatók fenn.

Egyelöre talányos, mennyire életképesek a fajhibridek, hogy egyáltalán stabilizálódott-e már annyira a genomjuk, hogy fennmaradjanak a természetben, vagy kialakulatlanságuk miatt eltủnnek egy idő után. Kérdés az is, mi lesz a sorsuk a szaprotróf fajokból kialakult és egyelőre szaprotrófnak mutatkozó hibrideknek. Vajon idővel eltűnnek, vagy folytatják eredeti életmódjukat, netán parazitává avanzsálnak? Túlélésre általánosan úgy van leginkább esélyük, ha életerősebbek és agresszívabbak a szülőfajoknál és/vagy azokéhoz képest gazdanövénykörük is bővül, ahogy ez a legtöbb ismert hibridre érvényes.

Az eddig megismert fitoftórafajokon kívül jó néhány, egyes tulajdonságaiban már ismert faj-, illetve hibridjelölt vár szakszerü leírásra. És hogy mi várható még? Nos, több százra becsülhető a természetben még megbúvó fitoftórák száma, ami arra utal, hogy a közeljövőben is folytatódik az elmúlt két évtizedben tapasztalt fajszámgyarapodás.

Az új fajok között lehetnek olyanok, amelyek már régóta jelen vannak a természetben, de olyanok is, amelyek új evolúciós folyamatok eredményeként alakultak ki, részben természeti hatásokra, részben pedig emberi tevékenység következtében. Ez utóbbi kapcsán említendő például az öntözéses termesztés, a különböző kémiai anyagok mutagén hatásai, nem utolsósorban pedig a világkereskedelem kiszélesedése, amely által nagyobb valószínüséggel kerülnek növények és/vagy kórokozóik új, szokatlan feltételek közé. E tényezők külön-külön vagy együttesen 
a meglévő fajok gazdanövénykörének módosulását, netán bővülését is kiválthatják, illetve terjedésüket gyorsíthatják. Mindenesetre az ilyen folyamatok komoly zavarokat okozhatnak a növényegészségügyi intézkedésekben.

\section{HOGYAN TOVÁBB?}

Az olyan fajok és fajhibridek esetében, amelyek egyelöre csak lokalizáltan bukkantak fel, általános szakmai érdek a földrajzi izoláció fenntartása a behurcolás lehetőség szerinti megakadályozásával. E tekintetben nagy jelentőségủ a karanténintézkedések szigorú betartása; hazánkban - bár előfordulását még nem jelezték - az amerikai tölgyesek hirtelen pusztulásáért és más növények megbetegedéséért is felelös $P h$. ramorum például zárlati listán van.

Amennyiben mégis megjelenik egy elózőleg ismeretlen vagy nem honos kórokozó az országban, elsősorban arról kell gondoskodni, hogy a szaporításra, illetve továbbtelepítésre szánt növények mentesek legyenek az ilyen kórokozótól. Ehhez főleg a kertészetek és faiskolák növényállományának szürővizsgálata szükséges. Egy ilyen program végrehajtásához - nem utolsósorban pedig a leginkább veszélyeztetett gazdasági növények rezisztenciára nemesítéséhez - azonban nélkülözhetetlen a gyors és megbízható diagnosztikai eljárások alkalmazása.

A molekuláris módszerek fejlődésének köszönhetően ma már fajspecifikus molekuláris markerekkel akár a fertőzött növényi szövetből is diagnosztizálható az adott Phytophthora-faj, ahogy az például az égerfitoftóra esetében ismert (Bakonyi et al., 2006). A gyors diagnózis lehetővé teszi az időben történő védekezési eljárás kidolgozását.

Ami a vegyszeres védekezést illeti, több buktató is adódik. Egyrészt természetes ökoszisztémában nem alkalmazható, másrészt a fitoftórák az általános fungicidekre nem érzékenyek, sajátos vegyszereket igényelnek. A kontaktszerek közül elsősorban a rézvegyületek jöhetnek szóba, a hatékonyabb felszívódó hatóanyagokkal (például metalaxil, cimoxanil, dimetomorf) viszont az a probléma, hogy a kórokozó populációiban előbb-utóbb kialakulnak és felszaporodnak az alkalmazott szerrel szemben rezisztens egyedek. Ilyen esetben a szerkoncentráció növelése hiábavaló, hiszen még a nagyságrendekkel nagyobb töménység is hatástalan. Megoldást jelenthet egy másik, eltérő hatásmechanizmusú szer bevetése, akár rotációban, akár kombinációban. Két hatóanyaggal szemben ugyanis lényegesen kisebb a szerrezisztencia kialakulásának valószínűsége. Nehezíti a védekezést az is, hogy az ivaros szaporodásra képes fajok ivaros spórái, az oospórák éveken át fennmaradnak a talajban maradt növényi részeken.

Vannak tehát veszélyek, ebből adódóan pedig megoldásra váró feladatok! Ez Magyarországra is vonatkozik, hiszen huszonhárom Phytophthora-fajt már nálunk is azonosítottak különbözö ökoszisztémákban. Hazánkban a fitoftórák ku- 
tatása az MTA Agrártudományi Kutatóközpont Növényvédelmi Intézetében és a Nyugat-magyarországi Egyetem Erdőmérnöki Karán folyt, illetve folyik. A témával kapcsolatos legteljesebb és legújabb ismeretek, valamint azok részletes irodalma pedig Érsek Tibor és Willem A. Man in ,t Veld (2013), illetve Érsek (2017) munkáiban összegződnek.

\section{IRODALOM}

Bakonyi, J. - Nagy, Z. Á. - Érsek T. (2006): PCR-based Markers for Identifying Hybrids within Phytophthora alni. Journal of Phytopathology, 154, 168-177. DOI 10.1111/j.14390434.2006.01079.x, https://www.researchgate.net/publication/229508181_PCR-based_DNA_ Markers_for_Identifying_Hybrids_within_Phytophthora_alni

Brasier, C. M. - Kirk, S. A. - Delcan, J. et al. (2004): Phytophthora alni sp. nov. and Its Variants: Designation of Emerging Heteroploid Hybrid Pathogens Spreading on Alnus Trees. Mycological Research, 108, 1172-1184. DOI: 10.1017/S0953756204001005, https://bit.ly/2kpaM7a

Érsek T. (2017): A növénypusztitó - A Phytophthora-nemzetség múltja és jelene. Györ: Universitas-Györ Nonprofit Kft.

Érsek T. - English, J. T. - Schoelz, J. E. (1995): Creation of Species Hybrids of Phytophthora with Modified Host Ranges Using Zoospore Fusion. Phytopathology, 85, 1343-1347. DOI:10.1094/ phyto-85-1343

Érsek T. - Man in ,t Veld, W. A. (2013): Phytophthora Species Hybrids: A Novel Threat to Crops and Natural Ecosystems. In: Lamour, K. (ed.): Phytophthora: A Global Perspective. Wallingford, UK: CAB International, 37-47.

Erwin, D. C. - Ribeiro, O. K. (1996): Phytophthora Diseases Worldwide. St. Paul, MN, USA: APS Press

Kamoun, S. - Furzer, O. - Jones, J. D. G. et al. (2015): The Top 10 Oomycete Pathogens in Molecular Plant Pathology. Molecular Plant Pathology, 16, 413-434. DOI: 10.1111/mpp.12190, https:// bsppjournals.onlinelibrary.wiley.com/doi/10.1111/mpp.12190 